\title{
Investigating the Perceptions of Pakistani English Language Learners on Language Learning Anxiety in EFL Classroom
}

\author{
Nasreen Bhatti \\ English Language Development Centre, Mehran University of Engineering and Technology, Jamshoro, Sindh, Pakistan \\ Shumaila Memon (Corresponding author) \\ University of Sindh, Jamshoro, Sindh, Pakistan \\ E-mail: sh.memon@hotmail.com \\ Habibullah Pathan \\ English Language Development Centre, Mehran University of Engineering and Technology, Jamshoro, Sindh, Pakistan
}

Doi:10.7575/aiac.alls.v.7n.5p. 23

URL: http://dx.doi.org/10.7575/aiac.alls.v.7n.5p.23
Received: 09/05/2016

Accepted: 07/07/2016

\begin{abstract}
This quantitative study aims to investigate the perceptions of English Language Learners on Language learning Anxiety in EFL classroom. Participants of the study were 145 Intermediate level students of different public colleges of Hyderabad, Sindh who are learning English as a foreign language. The data was collected through the modified form of Foreign Language Classroom Anxiety Scale (FLCAS) by Horwitz et al., (1986). Findings of this study reveal the causes of foreign language anxiety from the learners' perceptions such as communication apprehension was identified as the main cause of anxiety followed by the learners' self-perceived proficiency, fear of being negatively evaluated and nervousness as other sources of anxiety. However, their motivational intensity is higher to learn English. Based on the findings of the study, many of the suggestions are recommended for language teacher however it is also considered that language anxiety is a multi-faceted and complicated in nature which needs further exploration.
\end{abstract}

Keywords: Perceptions, Pakistani language learners, EFL classroom

\section{Introduction}

In past, the focus of research in discipline of foreign language teaching \& learning has been restricted to teacher and teaching. It witnessed a significant shift to learner and learning with the rise of humanistic approach which witnessed the learner's feelings and emotions as an inevitable factor in language learning (Ormeci, 2013). Among affective variables, the foreign language anxiety has been recognized as the most important factor influencing L2 learning success \& many studies have been conducted to explore it since the 1970s. Oxford (1999) opined that language anxiety ranks high among factors influencing foreign language learning.

Learning English as a foreign language has always been a challenging for Pakistani students. Majority of the learners recognize their failure of learning English as a foreign language as an inability to speak English in language classroom which results in feeling of stress, uneasiness, nervousness and their fear of being evaluated negatively. It, in turn, impedes their language learning. Recognizing anxiety as a deterring factor that can hinder learner to succeed in learning English as foreign language, it needs continuous investigation in local context of Sindh where is a very limited number of studies about the language anxiety at intermediate student's level. . The major concern of the research is the causes of anxiety from learner's perspective. How does the learner experience it? Therefore, this study attempts to investigate Pakistani language learners' perspectives on language learning anxiety with the purpose of exploring the factors which make them anxious in learning English language. It is expected that by recognizing anxiety provoking factors, Pakistani EFL teachers can help their learners to overcome them for effective language learning.

\section{Literature Review}

\subsection{Anxiety: Definition}

Anxiety was restricted to psychological domain for long \& therefore defined in context of psychology as " $a$ specific state of unpleasure accompanied by motor discharge along definite pathways" (Bunker, 1936:70). Psychologists modified it further as "the subjective feeling of tension, apprehension, nervousness, and worry associated with an arousal of the autonomic nervous system” (Spielberger, 1983, in Horwitz, 2001, p. 113).

With the flexible approach of witnessing Anxiety construct out of Psychological context, number of studies were conducted (Bailey,1986; Ching, Horwitz \& Shallert, 1999; Hilleson, 1996; Horwitz, Horwitz \& Cope,1986; Young, 1991) to study Anxiety as the most influencing affective factor in foreign language learning \& has been the center of 
interest for researchers in language study. The disciplines of psychology, Education, anthropology \& linguistics share the common definition of anxiety as the fear, apprehension, frustration, uneasiness $\&$ threat. However researchers have defined Anxiety in various ways.

In $19^{\text {th }}$ century, anxiety was dealt more as external threatening agent as in words of Darwin (1872) Anxiety is an emotional reaction when an organism feels himself threatened physiologically.

At the beginning, anxiety \& fear were used interchangeably as Freud (1925) assumed anxiety similar to fear and fright. Similarly, Lewis (1970: 63) defines anxiety as "an unpleasant emotion experienced as dread, scare, alarm, fright, trepidation, horror or panic".

In following decades, the anxiety was assumed as feeling of fear related indirectly to objects only as in words of Scovel "Anxiety is an apprehension, a vague fear that is only indirectly associated with an object" (1975, p. 134).

\subsection{Types of Anxiety}

Trait Anxiety: Spielberger (1983) defined trait anxiety as a general tendency to become nervous in a wide range of situations. Therefore, anxiety is a feature of an individual's personality and people with high trait anxiety remains anxious in different kind of situations.

State Anxiety: "It is a transitory state or condition of the organism that varies in intensity and fluctuates over time" (Spielberger, 1966, p. 12) a feeling of worry or stress that an individual experiences at a particular moment under a particular circumstance. It is often accompanied by physical signs such as perspiration, sweaty palms, dry mouth, muscle contractions and tension, and increased heart rate. It is experienced before taking test (Spielberger: 1983).

Transfer/Unique Theory: In 1986, the researchers' interest grew to know how anxiety affects language learning. It resulted emergence of two approaches termed as "anxiety transfer" and "unique anxiety" by Horwitz \& Young (1991). The anxiety transfer approach assumed L2 anxiety as a transfer of other forms of anxiety to the learning situation. This approach assumes that anxiety in foreign language learning is common for a person who experiences anxiety in other situations.

On the other hand, the contrasting approach of unique anxiety assumed that some types of anxiety are specific to the language acquisition context.

Situation-Specific Anxiety: Oh (1990) considers foreign language anxiety as a "situation-specific anxiety that students experience in the classroom which is characterized by self-centered thoughts, feelings of inadequacy, fear of failure, and emotional reactions in the language classroom" (p. 56).

The term "specific" is used to differentiate individuals who may be generally anxious in various situations from those who are only anxious in specific situations such as L2 classroom (Horwitz et al, 1986; MacIntyre \& Gardner, 1994). MacIntyre and Gardener (1993) consider foreign language anxiety as a situation specific anxiety that refers to the fear experienced by learner when a situation requires use a foreign language and the learner is not proficient to use it. Horwitz et al consider the foreign language anxiety as a responsible factor for students' negative emotional reactions to language learning because of the reason that they encounter foreign culture and language. Moreover, after some empirical studies, researchers consider language anxiety distinct from any other type of anxiety and are not merely a composite of other anxieties (Horwitz, Horwitz, \& Cope, 1986; MacIntyre \& Gardner, 1991b)

Facilitating Anxiety and Debilitating Anxiety: In 1977, kleinmann identified anxiety into two constructs: facilitating and debilitating ( Scovel 1991:18). They are distinguished on the basis of the effect they produce. According to Young (1990), facilitating anxiety is positive force which results in improved Performance while debilitating anxiety is negative force which leads to poor performance.

The presence of both kinds of anxiety in a same individual is asserted by Alpert and Haber (1960) "an individual may possess a large amount of both anxieties, or of one but not the other, or of none of either” (p. 213).

Foreign Language Anxiety: Since 1970's, the researchers used broad definitions of language anxiety. The definition provided by Horwitz, Horwitz, and Cope is commonly accepted definition of foreign language Anxiety. They defined FLA as

"A distinct complex construct of self-perceptions, beliefs, feelings, and behaviors related to classroom language learning arising from the uniqueness of language learning process."

(1986: p. 128)

Similarly, Clement (1980) confirms it by stating foreign language anxiety "a complex constructs that deals with learners' psychology in terms of their feelings, self-esteem, and self-confidence."

In a same way, Young (1992) defines foreign language anxiety as "a complicated psychological phenomenon peculiar to language learning." Brown (1993) states anxiety as the feelings of uneasiness, frustration, self-doubt, apprehension and worry.

Further, MacIntyre and Gardner (1994) add by defining it as the feeling of fear specifically related to the second language text i.e. speaking, listening. They further define it as a negative emotional reaction arousal while learning or using a second or foreign language". 
To Zhang (2001) while performing any learning task when learner experiences the psychological tension it is anxiety. Richards and Schmidt (2002) defines language anxiety as the feeling of fear and apprehension which lie in the language learning and its use.

\subsection{Causes and effects of Foreign Language Anxiety}

Horwitz et al (1986) explored that foreign language anxiety is related to performance evaluation in academic and social context and suggested three types of anxiety in context of performance:

(1) Communication apprehension (CA); (2) test anxiety (TA); and (3) fear of negative evaluation (FNE). Communication apprehension is defined as a fear or apprehension which learner experiences during communicating with people. McCroskey (1978) defines communication apprehension as a level of fear of an individual, related to either real or anticipated communication with other person. Horwitz, Horwitz and Cope consider interpersonal interactions as an important component of English Class where learner requires participating in oral task which does not only include learning language but it needs them to perform it as well that is why they view communication apprehension differently in foreign language class as compared to other context.

In addition, Ely (1986) and Phillips (1992) state this situation in a way that very anxious students are more likely to avoid the foreign language class or to withdraw from courses with several communication demands. Test anxiety is another performance related anxiety proposed by Horwitz et al (1986). They define test anxiety as "a type of performance anxiety stemming from a fear of failure". According to Sarason (1 984), the reason for test anxiety lies in a negative thoughts developed by students as a result of poor performance in the past during test-taking situations. It results students distraction during class which inhibits their performance in foreign language classrooms. According to Horwitz et al. (1986) test anxious students often put false beliefs in language learning and they set impractical expectations for themselves and do not accept anything less than a perfect performance in test if so they consider it failure. The third type of performance anxiety identified by Horwitz et al. (1986) is fear of negative evaluation. It is defined as "an apprehension about others' evaluations, avoidance of evaluative situations, and the expectation of negative evaluation from others." (Horwitz etal. 1986). Although, it shares the similarity with test anxiety but it differs in occurring in broader context from social to evaluative situations like job interview or speaking in front of the class. (Horwitz et al., 1986). It is associated to learner's assumption that he/she gets fail to achieve the social impression. In foreign language classrooms, students out of fear of negative evaluation avoid participation in such activities which requires them to be judged. (Aida, 1994)Such situation can be giving personal opinions or participation in discussion by giving volunteer answers. (Ely, 1986).

According to Awan, R., Azher, M., Anwar, M. N., \&amp; Naz, A. (2010), Young (1991) recognized the six possible sources of foreign language anxiety: (1) personal and interpersonal issues, (2) instructor learner interactions, (3) classroom procedures, (4) language testing, (5) instructor beliefs about language learning, and (6) learner beliefs about language learning. In 2004, Chan \& Wu highlight the teacher-students interactions in class, classmates' attitudes, teachers' attitude and evaluation, students' own achievements and parents' expectations as the possible sources of students' foreign language anxiety other than task difficulty. (p. 290). The other possible causes, studied in recent years, are the age (Bailey, et al., 2000), motivation (Yan, \& Horwitz, 2008), emotional intelligence (Awan, Sabir \& Iqbal, 2009), and with leaning difficulties (Chen \& Chang, 2004). MacIntyre proposes five possible major effects of anxiety on second/foreign language learning in different domains of learner's life. At first, it effects majorly on academic performance of learner. Learner with high level of anxiety has the lower level of language proficiency. Secondly, it effects the social life of learner. Anxious learners avoid to be the part of interpersonal communication with others. Thirdly, Anxiety effects the cognition of learners. Krashen (1982) sees affective filter as a kind of psychological filter which can either promote or prevent language input process. Anxiety can reduce learner's comprehension level which limits his language input. Fourthly, the arousal of anxiety can affect the quality of communication output by resisting the retrieval of information. At last, it may have unpleasant influence on the personality of learners by challenging his self-esteem.

\subsection{Previous research on Anxiety}

In 1970s and early 1980s, a number of studies were conducted to identify the relationship of anxiety and language learning which resulted inconsistency. The results showed contradictory results based on relationship between anxiety and L2 achievement. (Tallon: 2009) Explaining it further, some studies reported a negative relationship between language anxiety and achievement (Clément, Gardner, \&Smythe, 1977, 1980) and others reported little or a positive relationship (Chastain, 1975; Scovel, 1978).In 1978, Scovel made an attempt to find out the reasons for such contradictory result and he came up with the reason that there was lack of adequate appropriate instrument to measure anxiety which resulted in contradictory results. Similarly, Gardner and MacIntyre (1993a) believe that using general measures of anxiety is the reason for contradictory results. In recent years, Horwitz $(2001: 121)$ has restated that the understanding the relationship between language anxiety and achievement is unresolved issue. The cause for the confusion in results is rightly stated by Philip (cited in Ebrahimi, 2013: 183):

"a comparison of the experimental research examining the relationship between anxiety and second language learning is, to a degree, perplexing, presenting some conflicting evidence and illustrating that anxiety is a complex, multi-faceted construct."

\subsection{Research Question}

The present research addresses the following question: 
- What are the perceptions of learners about language class anxiety in the context of English language learning at public colleges in Hyderabad, Pakistan?

\section{Methodology}

\subsection{Participants}

The participants of this study were second year Intermediate EFL students at Government colleges which were 4 in number, two of them boys' colleges and two of them are girls' colleges. English study is compulsory for second year intermediate students. In order to ensure that the sample collected was representative of the whole sampling population, the current study adopted a random sampling technique: In this way, random section of intermediate class was selected from each college to participate in the present study. For the purposes of the study, a number of factors related to the students' background were also controlled. All of the participants needed to satisfy the following two criteria: 1) the participant was a non-native speaker of English, and 2) the participant had studied English for at least 6 years in junior and senior high school. In total, there were 150 students in the four selected classes. After administering the questionnaires, it was found that five of the students did not fully complete the questionnaires and their data were discarded, leaving a total sample population of 145 students. Among the 145 participants, $85(48.6 \%)$ were males and 90 (5 1.4\%) were females Forty-two (43.7\%) second year students were males and $54(56.3 \%)$ were females. The participants ranged in age from 16 to 19.All the subjects had studied English for least six years in junior and senior high school.

\subsection{Instruments}

The instrument used in the current study was The Foreign Language Classroom Anxiety Scale (FLCAS), (Horwitz et al., 1986). It consists of 33 items whereas only 20 items were selected from foreign language classroom Anxiety scale (FLCAS) for current research study. The 33 items are distributed in two groups. One of them represents high anxiety and other represents lack of anxiety. For the current study, the selection of high anxiety group was made. This narrowed selection of items proved helpful in remain specific to one aspect of anxiety and resulted focused output. The selected items were $3,4,6,9,10,12,13,15,16,17,20,21,23,24,25,26,27,30,31,33$ four of the selected items of FLCAS are linked to Communication Apprehension. These are (9, 20, 24 and 27). There is only one item connected to Test Anxiety (21). Even of them $(3,10,13,25,30,31$, and 33) are associated with the Fear of Negative Evaluation. Two of them are related to Self-perceived proficiency (4 and 15), one is comparison (23), three of them related to nervousness (12, 16 and 26), and two of them associated with motivational intensity (6 and 17). The FLCAS items are answered on a 5point Likert scale, ranging from 1) "Strongly agree" 2) "Agree" 3) "neither agree nor disagree," 4) Disagree to 5) "Strongly Disagree." However, the option "neither agree nor disagree," was omitted for the possibility of using it to avoid real choice by participants. To avoid any confusion that may result from using the original FLCAS which was developed in English, the FLCAS questionnaire was translated into mother tongue of students (Urdu/ Sindhi) to lessen students' misunderstandings. The reason to choose this scale for the study lies in the fact that the foreign language classroom Anxiety Scale (Horwitz et al., 1986) has been widely employed instrument in its original, translated or adapted form for foreign language Anxiety associated researches. It is observed as reliable scale which has been adopted by many studies as a tool of choice. FLCAS proved the reliable scale for its consistent results (Horwitz 1986; Aida, 1994; Rodrigues \& Abreu, 2003). In one sample of 108 students (Horwitz, 1986), the internal reliability measure of the FLCAS showed an alpha coefficient of .93, and test-retest reliability over a period of eight weeks was $\mathrm{r}=.83$ $(\mathrm{p}<.001)$.

\subsection{Data Collection Procedures}

There were four intermediate Government colleges were selected which consented for students' participation in the research. Two of them were Boys' Colleges and two of them were Girls' Colleges. From each college, second year class of intermediate was selected participate in the study which resulted in participation of four classes from four Colleges. As mentioned before, the selection of class section was random. Subsequently, the researcher visited each college at a pre-arranged class time and accompanied to the target class by one of teachers of English department of each college who cooperated fully in the implementation of the study. Then, the Researcher informed the students about the purposes of the research. Afterwards, the students of these selected classes who met the criteria for participation were invited to participate in the study voluntarily. A Consent letter to ask permission for students' participation in the research and the FLCAS and SES questionnaires with Urdu and Sindhi translation were distributed among the students of these selected classes, bearing in mind their Mother tongue. . Students were informed both verbally and in the consent letter that participation in the research was completely voluntary. One hundred and fifty students of the four selected classes completed the questionnaires and returned to the researcher. It took the participants 30 to 40 minutes to finish the questionnaires. Out of 150 questionnaires, five were not filled completed therefore they were discarded. As a result, the total number of questionnaires was 145 which were filled completely and appropriately.

\section{Results and Discussion}

Table 1. I tremble when I know that I am going to be called on in language class

\begin{tabular}{cccccc}
\hline & & Frequency & Percent & Valid Percent & Cumulative Percent \\
\hline \multirow{3}{*}{ Valid } & Strongly Agree & 39 & 26.9 & 26.9 & 26.9 \\
\cline { 2 - 6 } & Agree & 70 & 48.3 & 48.3 & 75.2 \\
\cline { 2 - 6 } & Disagree & 28 & 19.3 & 19.3 & 94.5 \\
\cline { 2 - 6 } & Strongly Disagree & 5 & 5.5 & 5.5 & 100.0 \\
\cline { 2 - 6 } & Total & 145 & 100.0 & 100.0 & \\
\hline
\end{tabular}


The foreign language learning class usually requires learners to participate in class discussions, to debate, to speak voluntarily and to contribute to lessons through the asking and answering of questions. Therefore, the anxious Learners are more likely to experience even higher communication apprehension in a foreign language class. As shown in the above table 01, the result regarding the statement reveals that only the quarter of the percentage of subjects disagreed to the statement whereas the higher percentage of the subjects around $74 \%$ agreed to the statement. It indicates that many of the subjects had an inclination to be more likely to experience communication apprehension in their English classes.

Table 2. It frightens me when I don't understand what the teacher is saying in the foreign Language

\begin{tabular}{cccccc}
\hline & & Frequency & Percent & Valid Percent & Cumulative Percent \\
\hline Valid & Strongly Agree & 21 & 14.5 & 14.5 & 14.5 \\
\cline { 2 - 5 } & Agree & 54 & 37.2 & 37.2 & 51.7 \\
\cline { 2 - 5 } & Disagree & 49 & 33.8 & 33.8 & 85.5 \\
\cline { 2 - 5 } & Strongly Disagree & 21 & 14.5 & 14.5 & 100.0 \\
\cline { 2 - 5 } & Total & 145 & 100.0 & 100.0 & \\
\hline
\end{tabular}

The result of the above given statement Indicates the Language learners' self-perception of target language ability. Approximately equal percentage of participants agreed as well half of them disagreed that they feel anxious about learning English in relation to their self-perceived proficiency.

Table 3. During Language class, I find myself thinking about things that have nothing to do with course

\begin{tabular}{cccccc}
\hline & & Frequency & Percent & Valid Percent & Cumulative Percent \\
\hline Valid & Strongly Agree & 10 & 6.9 & 6.9 & 6.9 \\
\cline { 2 - 5 } & Agree & 41 & 28.3 & 28.3 & 35.2 \\
\cline { 2 - 5 } & Disagree & 56 & 38.6 & 38.6 & 73.8 \\
\cline { 2 - 5 } & Strongly Disagree & 38 & 26.2 & 26.2 & 100.0 \\
\cline { 2 - 5 } Total & 145 & 100.0 & 100.0 &
\end{tabular}

However, results for the above given statement suggest the higher percentage (64\%) is of the participants who disagreed to it. It points out that their motivational intensity is higher in EFL class.

Table 4. I start to panic when I have to speak without preparation in language class

\begin{tabular}{cccccc}
\hline \multirow{2}{*}{ Valid } & Frequency & Percent & Valid Percent & Cumulative Percent \\
\cline { 2 - 6 } & Strongly Agree & 57 & 39.3 & 39.3 & 39.3 \\
\cline { 2 - 5 } & Agree & 59 & 40.7 & 40.7 & 80.0 \\
\cline { 2 - 5 } & Disagree & 22 & 15.2 & 15.2 & 95.2 \\
\cline { 2 - 5 } & Strongly Disagree & 7 & 4.8 & 4.8 & 100.0 \\
\hline
\end{tabular}

This is another statement in relation to communication apprehension. In response to this statement, indicating speaking English without preparation, a huge number of students experience anxiety. 79 percentage of subjects' agreement to the statement shows that the EFL Learners are likely to experience higher communication apprehension in an English language class.

Table 5. I worry about the consequences of failing my foreign language class

\begin{tabular}{cccccc}
\hline & & Frequency & Percent & Valid Percent & Cumulative Percent \\
\hline Valid & Strongly Agree & 42 & 29.0 & 29.0 & 29.0 \\
\cline { 2 - 5 } & Agree & 49 & 33.8 & 33.8 & 62.8 \\
\cline { 2 - 5 } & Disagree & 25 & 17.2 & 17.2 & 80.0 \\
\cline { 2 - 5 } & Strongly Disagree & 29 & 20.0 & 20.0 & 100.0 \\
\cline { 2 - 5 } & 145 & 100.0 & 100.0 & \\
\hline
\end{tabular}


The results suggest that 62 percentage of EFL learners supported the above given statement Whereas 37 percentage of EFL learners rejected the statement. It indicates that majority of EFL learners are afraid of being evaluated negatively.

Table 6. In language class, I can get so nervous I forget things I know

\begin{tabular}{cccccc}
\hline \multirow{2}{*}{ Valid } & Frequency & Percent & Valid Percent & Cumulative Percent \\
\cline { 2 - 5 } & Strongly Agree & 22 & 15.2 & 15.2 & 15.2 \\
\cline { 2 - 5 } & Agree & 56 & 38.6 & 38.6 & 53.8 \\
\cline { 2 - 5 } & Disagree & 40 & 27.6 & 27.6 & 100.0 \\
\hline Strongly Disagree & 27 & 18.6 & 18.6 & \\
\hline Total & 145 & 100.0 & 100.0 & \\
\hline
\end{tabular}

Moreover with the reference to the above given statement, half of the participants agreed to it as well as half of them disagreed to it.

Table 7. It embarrasses me to volunteer answers in my language class

\begin{tabular}{cccccc}
\hline \multirow{2}{*}{ Valid } & Frequency & Percent & Valid Percent & Cumulative Percent \\
\cline { 2 - 5 } & Strongly Agree & 15 & 10.3 & 10.3 & 10.3 \\
\cline { 2 - 5 } & Agree & 38 & 26.2 & 26.2 & 36.6 \\
\cline { 2 - 5 } & Disagree & 49 & 33.8 & 33.8 & 70.3 \\
\cline { 2 - 5 } Strongly Disagree & 43 & 29.7 & 29.7 & 100.0 \\
\hline Total & 145 & 100.0 & 100.0 & \\
\hline
\end{tabular}

In response to the above statement, majority of participants showed strong disagreement that they feel embarrassed when they want to volunteer answers in their language class. while only 36 percentage of EFL subjects agreed to it. It reveals that most of the EFL learners do not feel afraid of being evaluated negatively.

Table 8. I get upset when I don't understand what the teacher is correcting

\begin{tabular}{cccccc}
\hline & & Frequency & Percent & Valid Percent & Cumulative Percent \\
\hline Valid & Strongly Agree & 21 & 14.5 & 14.5 & 14.5 \\
\cline { 2 - 5 } & Agree & 51 & 35.2 & 35.2 & 49.7 \\
\cline { 2 - 5 } & Disagree & 49 & 33.8 & 33.8 & 83.4 \\
\cline { 2 - 5 } & Strongly Disagree & 24 & 16.6 & 16.6 & 100.0 \\
\cline { 2 - 5 } & Total & 145 & 100.0 & 100.0 & \\
\hline
\end{tabular}

The results reveal the self-perceived proficiency stating the Perception of high ability of EFL learners regarding learners' performance in English class. The half of the subjects have negative self-perception about their proficiency simultaneously, half of the subjects have positive self-perception about their proficiency in English Class.

Table 9. Even if I am well prepared for language class, I feel anxious about it

\begin{tabular}{cccccc}
\hline & & Frequency & Percent & Valid Percent & Cumulative Percent \\
\hline \multirow{2}{*}{ Valid } & Strongly Agree & 40 & 27.6 & 27.6 & 27.6 \\
\cline { 2 - 5 } & Agree & 59 & 40.7 & 40.7 & 68.3 \\
\cline { 2 - 5 } & Disagree & 25 & 17.2 & 17.2 & 85.5 \\
\cline { 2 - 5 } & Strongly Disagree & 21 & 14.5 & 14.5 & 100.0 \\
\cline { 2 - 6 } & Total & 145 & 100.0 & 100.0 & \\
\hline
\end{tabular}

However, 67 percentage of the subjects endorsed the above item reflecting nervousness. Only quarter of the participants disagreed to it. It further indicates that though students are fully prepared for the language class but they still feel anxious to respond in class. 
Table 10. I often feel like not going to my language class.

\begin{tabular}{cccccc}
\hline & & Frequency & Percent & Valid Percent & Cumulative Percent \\
\hline Valid & Strongly Agree & 15 & 10.3 & 10.3 & 10.3 \\
\cline { 2 - 5 } & Agree & 17 & 11.7 & 11.7 & 22.1 \\
\cline { 2 - 5 } & Disagree & 37 & 25.5 & 25.5 & 47.6 \\
\cline { 2 - 5 } & Strongly Disagree & 76 & 52.4 & 52.4 & 100.0 \\
\cline { 2 - 5 } & 145 & 100.0 & 100.0 & \\
\hline
\end{tabular}

In addition, the above said item reflects majority of the responses reporting disagreement to the statement. Whereas only 21 percentage of them agreed to it. The results showed motivational intensity as the result of pace of maintaining the determination and Persistence while encountering unfamiliar and challenging situations.

Table 11. I can feel my heart pounding when I am going to be called on in language class

\begin{tabular}{cccccc}
\hline & & Frequency & Percent & Valid Percent & Cumulative Percent \\
\hline Valid & Strongly Agree & 43 & 29.7 & 29.7 & 29.7 \\
\cline { 2 - 5 } & Agree & 65 & 44.8 & 44.8 & 74.5 \\
\cline { 2 - 5 } & Disagree & 26 & 17.9 & 17.9 & 92.4 \\
\cline { 2 - 5 } & Strongly Disagree & 11 & 7.6 & 7.6 & 100.0 \\
\cline { 2 - 5 } & Total & 145 & 100.0 & 100.0 & \\
\hline
\end{tabular}

The communication apprehension is evident through the above given statement Which reports 73 percentage of responses agreed recognizing the subjects communicatively anxious and only 24 percentage of them did not feel fearful while communicating in English class.

Table 12. The more I study for language class, the more confused I get

\begin{tabular}{cccccc}
\hline & & Frequency & Percent & Valid Percent & Cumulative Percent \\
\hline \multirow{2}{*}{ Valid } & Strongly Agree & 24 & 16.6 & 16.6 & 16.6 \\
\cline { 2 - 5 } & Agree & 45 & 31.0 & 31.0 & 47.6 \\
\cline { 2 - 5 } & Disagree & 46 & 31.7 & 31.7 & 79.3 \\
\cline { 2 - 5 } & Strongly Disagree & 30 & 20.7 & 20.7 & 100.0 \\
\cline { 2 - 5 } & Total & 145 & 100.0 & 100.0 & \\
\hline
\end{tabular}

In response to the above given item referring to Test anxiety, results report almost equal percentage of agreed and disagreed responses. The equal number of participants feel anxious for attempting test simultaneously half of them do not feel anxious for test.

Table: 13 I always feel that other students speak the foreign language better than I do

\begin{tabular}{cccccc}
\hline & & Frequency & Percent & Valid Percent & Cumulative Percent \\
\hline \multirow{3}{*}{ Valid } & Strongly Agree & 37 & 25.5 & 25.5 & 25.5 \\
\cline { 2 - 6 } & Agree & 63 & 43.4 & 43.4 & 69.0 \\
\cline { 2 - 6 } & Disagree & 32 & 22.1 & 22.1 & 91.0 \\
\cline { 2 - 6 } & Strongly Disagree & 13 & 9.0 & 9.0 & 100.0 \\
\cline { 2 - 5 } & Total & 145 & 100.0 & 100.0 & \\
\hline
\end{tabular}

The results report 68 as the highest percentage of the EFL subjects who compare their proficiency of English language with other students and find them better than themselves. Whereas only quarter of them disagreed to it. 
Table 14. I feel very self-conscious about speaking the foreign language in front of other students

\begin{tabular}{cccccc}
\hline & & Frequency & Percent & Valid Percent & Cumulative Percent \\
\hline \multirow{2}{*}{ Valid } & Strongly Agree & 34 & 23.4 & 23.4 & 23.4 \\
\cline { 2 - 5 } & Agree & 69 & 47.6 & 47.6 & 71.0 \\
\cline { 2 - 5 } & Disagree & 33 & 22.8 & 22.8 & 93.8 \\
\hline Strongly Disagree & 9 & 6.2 & 6.2 & 100.0 \\
\hline Total & 145 & 100.0 & 100.0 & \\
\hline
\end{tabular}

Speaking English in front of others is another stress point for EFL learner. He is afraid of perception of others. The findings suggest that the quarter of participants also disagreed with the above statement. In response of the above said statement, 70 percentage of the EFL learners agreed that they experience speaking anxiety while being evaluated by others.

Table 15. Language class moves so quickly I worry about getting left behind

\begin{tabular}{cccccc}
\hline & & Frequency & Percent & Valid Percent & Cumulative Percent \\
\hline Valid & Strongly Agree & 28 & 19.3 & 19.3 & 19.3 \\
\cline { 2 - 5 } & Agree & 54 & 37.2 & 37.2 & 56.6 \\
\cline { 2 - 5 } & Disagree & 38 & 26.2 & 26.2 & 82.8 \\
\cline { 2 - 5 } & Strongly Disagree & 25 & 17.2 & 17.2 & 100.0 \\
\cline { 2 - 5 } & Total & 145 & 100.0 & 100.0 &
\end{tabular}

Anxiety of Participants prevails for the above given statement that 56 percentages of subjects supported it. This confirms that they are anxious to be evaluated negatively. Whereas 47 percentage of them disagreed to the statement.

Table 16. I feel more tense and nervous in my language class than in any other classes

\begin{tabular}{cccccc}
\hline & Frequency & Percent & Valid Percent & Cumulative Percent \\
\hline Valid & Strongly Agree & 13 & 9.0 & 9.0 & 9.0 \\
\cline { 2 - 5 } & Agree & 30 & 20.7 & 20.7 & 29.7 \\
\cline { 2 - 5 } & Disagree & 50 & 34.5 & 34.5 & 64.1 \\
\cline { 2 - 5 } & Strongly Disagree & 52 & 35.9 & 35.9 & 100.0 \\
\cline { 2 - 5 } & Total & 145 & 100.0 & 100.0 & \\
\hline
\end{tabular}

Interestingly, there is completely opposite result for the statement "I feel more tense and nervous in my language class than in any other classes." In the comparison of the two of the previous statements exhibiting nervousness of learners in English class. 69 percentage of the learners rejected and quarter of them supported it.

Table 17. I get nervous and confused when I am speaking in my language class

\begin{tabular}{cccccc}
\hline & & Frequency & Percent & Valid Percent & Cumulative Percent \\
\hline Valid & Strongly Agree & 34 & 23.4 & 23.4 & 23.4 \\
\cline { 2 - 5 } & Agree & 52 & 35.9 & 35.9 & 59.3 \\
\cline { 2 - 5 } & Disagree & 35 & 24.1 & 24.1 & 83.4 \\
\hline Strongly Disagree & 24 & 16.6 & 16.6 & 100.0 \\
\hline Total & 145 & 100.0 & 100.0 & \\
\hline
\end{tabular}

The findings exhibit the more than half highest percentage of response of the subjects who recognized the communicative apprehension as their problem. Whereas 40 percent of them strongly agreed to it. 
Table 18. I feel overwhelmed by the number of rules you have to learn to speak a foreign Language

\begin{tabular}{cccccc}
\hline & & Frequency & Percent & Valid Percent & Cumulative Percent \\
\hline Valid & Strongly Agree & 28 & 19.3 & 19.3 & 19.3 \\
\cline { 2 - 5 } & Agree & 44 & 30.3 & 30.3 & 49.7 \\
\cline { 2 - 5 } & Disagree & 21 & 28.3 & 28.3 & 77.9 \\
\cline { 2 - 5 } & Strongly Disagree & 32 & 22.1 & 22.1 & 100.0 \\
\hline Total & 145 & 100.0 & 100.0 & \\
\hline
\end{tabular}

It can be reasoned that learning to speak a foreign language (English) requires a learner to learn a number of features of language such as pronunciation, accent, grammar, choosing and placing appropriate word at appropriate place to convey appropriate meaning with the greater chances of being under evaluation of other people. The results for above given statement reports 50 percent of agreed responses which is indicative of equal number of students being anxious and half of them are not.

Table 19. I am afraid that the other students will laugh at me when I speak the foreign language.

\begin{tabular}{cccccc}
\hline \multirow{2}{*}{ Valid } & Frequency & Percent & Valid Percent & Cumulative Percent \\
\cline { 2 - 5 } & Strongly Agree & 37 & 25.5 & 25.5 & 25.5 \\
\cline { 2 - 5 } & Agree & 27 & 18.6 & 18.6 & 44.1 \\
\cline { 2 - 5 } & Disagree & 49 & 33.8 & 33.8 & 77.9 \\
\cline { 2 - 5 } Strongly Disagree & 32 & 22.1 & 22.1 & 100.0 \\
\hline Total & 145 & 100.0 & 100.0 & \\
\hline
\end{tabular}

Table 20. I get nervous when the language teacher asks questions which I have not prepared in advance

\begin{tabular}{cccccc}
\hline \multirow{3}{*}{ Valid } & Frequency & Percent & Valid Percent & Cumulative Percent \\
\cline { 2 - 6 } & Strongly Agree & 48 & 33.1 & 33.1 & 33.1 \\
\cline { 2 - 6 } & Agree & 68 & 46.9 & 46.9 & 80.0 \\
\hline Disagree & 19 & 13.1 & 13.1 & 93.1 \\
\hline Strongly Disagree & 10 & 6.9 & 6.9 & 100.0 \\
\hline
\end{tabular}

The above two statements indicate the fear of being negatively evaluated and exhibits mixed results. The results for the statement "I am afraid that the other students will laugh at me when I speak the foreign language." Show 43 percentages of the subjects which shows agreement to it. However, on the contrary, the majority of the responses (79\%) agreed to the statement "I get nervous when the language teacher asks questions which I have not prepared in advance."

\section{Discussion}

The result yielded in the present study seem likely supportive to the findings proposed by the previous research on the area of language anxiety, however, it does not agree with every fact of previous research but it does have consistency with the findings suggesting students' perceptions on the anxiety in EFL context.

The findings proposed the strong association between EFL students 'perception about the English language learning and language anxiety. These students provided mixed responses towards the FLCAS items concerning nervousness and selfperceived proficiency. However, items related to Motivational intensity yielded opposite result to rest of the others. It indicates that a substantial number of the subjects in this study are motivated to learn English language. The motivation depends upon learner's beliefs which keeps fluctuating with the people around, their behavior and the nature of task. There can be many reason for being motivated to learn English. It may be short term gains like passing an exam (instrumental motivation), for any gain reward or to avoid punishment (extrinsic motivation) or long term gains like an internal desire to learn English (intrinsic motivation) and a desire to integrate with the speakers of that language (integrative motivation). Whereas in case of current study, the short term gains fit the context where students' motivation is for passing an exams, gaining rewards like good grades and marks or avoiding punishment. The study found communicative apprehension as the most anxiety provoking area. which is related to situation where students have to speak in English. The current studies of Cui (2011), Kashani and Vahid (2011), Arif, Mukminin, Maimonah, Masbirorotni, Noprival \& Sutarno (2015), have similar findings to this study among college students. This study explored that the college students have the feeling of anxiety in their English classrooms. The findings of these studies suggest that besides communicative apprehension the students are anxious of negative evaluation. The reasons for such 
results can be attributed to their English proficiency which hinders them to communicate with others confidently or speak their point of view adequately in class. In addition, it also resists in answering teachers' questions. Therefore the English language classrooms which is communication-based, college students are more anxious as compared to other classes. Tang (2005) pointed out that the alleviation of anxiety is possible with the contact with the people and culture of the target language. However, in Pakistani context, the socio-cultural, referring to culture of learner, social environment, aspect of EFL learning cannot be ignored. English is still the status-bound language. It is inevitable part of private colleges' classroom whereas in public colleges, English language does not enjoy that status which results less exposure to language and less practice of it for students. Moreover, most Language teachers in public colleges emphasize only two language skills majorly I.e. reading and writing, whereas listening and speaking are totally neglected skills in language classroom which resulted in communication anxiety levels students. The other attributing factor may be the books designed for teaching English at Public colleges are not intended to develop communicative competence of students. Therefore, students feel anxious while speaking English. It can also be added that the English learning/Teaching process is exam-oriented at public colleges. The exam is written therefore all focus of teachers are to teach English for written purpose. Presently, the use of authentic material and communicative language teaching approach are encouraged in language classes whereas in public colleges, Grammar Translation is still the most adopted teaching methodology for teaching English Language which does not help students to get exposure to the English language as a real-life language. Therefore, they are left behind others. Rote memorization of grammar rules and vocabulary push students into anxiety zone for they feel pressurized and overburden.

Wang (2003) attributes the existence of anxiety in English classrooms to classroom atmosphere. The EFL classrooms are teacher-centered at public colleges where teacher controls the class and does not give freedom to learners which results the lack of relaxed environment for English language learning. Consequently, students mostly feel anxious and nervous.

\section{Conclusion}

It is a matter of fact that the current research has provided a thoughtful understanding of language anxiety However Language Anxiety is a multi-faceted and complex issue which needs further exploration from a different aspect. The results of this study clearly indicate that in case of the language anxiety such situations which are likely to expose EFL learners' language failures or weaknesses stimulate language anxiety for them. According to the findings, the communicative apprehension is the most anxiety provoking factor it may be because in language class, Communicative tasks are the most challenging for EFL learners. Moreover, the results indicate that the other factor which makes foreign language classroom a highly anxiety-evoking place is its consistent evaluative nature. The EFL learner is continuously evaluated by the teachers and by his peers. The study found that the anxiety in EFL learners is also due to their feeling of low proficiency, Nervousness or lack of confidence. The main cause of these difficulties arousing from language anxiety was the lack of practicing particularly speaking skill in different social contexts. The lack of practice results from un regularization of English language usage inside or outside the classroom. They prove troubling for EFL learners. Furthermore, this fact cannot be avoided that they feel anxious communicatively because of the fear that it might affect negatively the image or self-identity which they have shaped in their L1 language. The past studies do not suggest any specific remedies for language anxiety. But according to Oxford (1999), The strategies recommended by the research studies " undoubtedly work as General treatment for anxiety but it might as easily be advice on 'what good teachers' should routinely do".

It can be proposed that language anxiety may not need any 'special treatment' but on the contrary it needs the understanding, sensitive and careful attitude of the language teachers which can help them to identify the language anxiety phenomenon among his EFL students. Furthermore, it requires the command and grip of language teachers over the modern approaches of language teaching which emphasize on alleviating language anxiety among learners in an environment that is contributing to an effective and productive language learning.

There are many recommendations suggested by the study for Language teachers which are discussed below:

\subsection{Recommendations}

- It is matter of fact that language anxiety exists in English language class irrespective of their language level, ability, gender and age therefore language Teachers should bear in mind that anxiety definitely affects EFL learners' participation. To cope with this problem, the teachers should design their language lessons and activities keeping the affective variables into consideration. Hembree (1988: cited in Ying-Ling \& Kondo: 2004: 259) presents the three approaches I.e. affective, cognitive and behavioral which can be considered for selecting a suitable strategy for language teaching and alleviating anxiety.

- Language learning process initiates with listening and speaking skills whereas the more focus is given by language teachers to written and reading skills therefore instead of being familiar with the English language since earlier classes, the level of anxiety grows with the growing age. The language teachers are suggested to reverse the pattern of language skills teaching and give more attention to communicative approach. The more listening stimulates speaking skill and more speaking will reduce their language anxiety.

- The comfortable, friendly, learning-supportive environment of the class may prove helpful in alleviating learners' anxiety which can result the active participation of learners in language class enjoyable and productive.

- The effort should be made for developing the sense of friendship and cooperation among the students. The collaborative learning strategy can work well for the students who are more anxious in language learning. It 
can increase connectivity and familiarity of learners to each other which will reduce the fear of negative evaluation by classmates and the sense of competition among them.

- In language class, students are found more conscious of making mistakes, teachers should prepare students to accept the fact that the process of learning language is impossible without making mistakes. They have to make mistakes to acquire communication skills.

- The formative assessment and feedback is recommended rather than summative assessment. It will be helpful in overcoming the EFL learner's fear of getting less marks or failing in language test.

- The use of Authentic material for language teaching is highly recommended for language teachers. The language tasks based on exposure to real life situations will connect learners to the outside world. Resultantly, they will not be anxious if they face real life situations which requires use of language.

- The language teachers should be familiar with the culture and ethnic background of the students. In addition, language teachers must know the background of learners 'previous language learning experiences. It can help teachers to understand the anxiety-related behaviors of EFL students.

\section{References}

Al-Hebaish, S.M. (2012). The correlation between general self-confidence and academic achievement in the oral presentation course. Theory and Practice in Language Studies, 2(1), 60-65. http://dx.doi.org/10.4304/tpls.2.1.60-65

Al-Saraj T.2011. Foreign language anxiety: what is it? Paper presented at 4th Bloomsbury Student Conference in Applied Linguistics, Birkbeck College, University of London, the UK, 2011.

Al-Saraj, T. M. (2014). Revisiting the foreign language classroom anxiety scale (FLCAS): The anxiety of female English language learners in Saudi Arabia. L2 Journal, 6, 50-76.

Retrieved from www.bbk.ac.uk/linguistics/conferenceHandbook2011.pdf

Ahmed, M., Esmail, A., Noreen, S. (2015) Role of Students' Motivation, Attitude and Anxiety in Learning English at Intermediate Level in Pakistan: A Gender Based Study. Educational Research International, 4(2).

Awan, R., Azher, M., Anwar, M. N., \&amp; Naz, A. (2010). An investigation of foreign language classroom anxiety and its relationship with students' achievement. Journal of College Teaching and Learning,7(11),33-33-40.

Retrieved from $h t t p: / /$ search.proquest.com/docview/818498103? accountid=15017

AY. S. (2010) A Young Adolescent Students' Foreign Language Anxiety in Relation to Language Skills at Different Levels. The Journal of International Social Research Volume 3(11).

Bamfield, V., M. (2014).Chinese Tertiary Students' Willingness to Communicate in English. Ph. D. Thesis.

Batiha, J., Mustaffa, R., \& Noor, N., M. (2014). Exploring the Factors of Classroom Anxiety in the Context of EFL Arab Students. International Journal of Social Science and Humanities Research, 2(2), 18-3.

Chan, D.Y.C. \& Wu, G.C. (2004). A Study of Foreign Language Anxiety of EFL Elementary School Students in Taipei County. Journal of National Taipei Teachers College, 17(2), 287-320 .

Ebrahimi, H.R.R. (2013). Anxiety as a Deterring Element in Learning English for Oral Communication among EFL Students. International Journal of Language Learning and Applied Linguistics World, 4(3), 179-196. Retrieved from www.ijllalw.org/finalversion4316.pdf

Effiong, O. (2013). Factors influencing foreign language classroom anxiety: An investigation of English learners in four Japanese universities (Doctoral dissertation). Retrieved from http://eprints.soton.ac.uk/id/eprint/367372

Gilakjani, A. P., and M. R. Ahmadi. 2011. A Study of Factors Affecting EFL Learners' English Listening Comprehension and the Strategies for Improvement. Journal of Language Teaching and Research, 2, 977-988.

Hayatdavoudi, J., Kassaian, Z. (2013). The Relationship between Language Anxiety and Psycho-Physiological Responses to Oral Performance: A Study on Iranian EFL Students

Horwitz, E. K., Horwitz,M-8., \& Cope, J. (1986). Foreign language classroom anxiety. The Modern Language Journal, $70,125-132$.

Humphries, R. (2011). Language anxiety in international students: How can it be overcome? Rebecca Humphries: Language Anxiety in International Students, 4(1/2), 65- 77.

Idri, N. (2012).Foreign language anxiety among Algerian EFL students: The case of first year students of English at the University of Abderahmane Mira-Béjaia; LMD (Licence/Master/Doctorat) system group. Universal Journal of Education and General Studies Vol. 1(3) pp. 055-064.

Jalali,L., \& Jalali, S. (2015) Study Of Foreign Language Classroom Anxiety And Its Relation With Creativity And Psychological Hardiness In English Majoring Students Of Velayat University Of Iranshahr. Indian Journal of Fundamental and Applied Life Sciences, 5(S1), 3989-3995

Liu, M., \& Huang, W. (2011). An Exploration of Foreign Language Anxiety and English Motivation. Education Research International, 1-8. http://dx.doi.org/10.1155/2011/493167 
Liu, M. (2007). Anxiety in Oral English Classroom; a Case Study in China. Indonesian Journal of English Language Teaching, 3(1), 119-137.

Lynch, J. (1996).A study of foreign language classroom anxiety in an intensive English program context. M.Ed. Thesis. Marwan A. 2007. Investigating students' foreign language anxiety. Malaysian Journal of ELT Research, 3, 37-55.

Melouah, A. (2013). Foreign Language Anxiety in EFL Speaking Classrooms: A Case Study of First-year LMD Students of English at Saad Dahlab University of Blida, Algeria. AWEJ, 4(1), $64-76$

Mohammadi, E., Biria, R., Koosha, M., \& Shahsavari, A. (2013). The relationship between foreign language anxiety and language learning strategies among university students. Theory and Practice in Language Studies, 3(4), $637-646$.

Nekouei, R., \& Talebinejad, M., R. (2013). The relationship between foreign language anxiety and belief toward FLL among children EFL learners. Basic Research Journal of Education Research and Review Vol. 2(3) pp. 49-54.

Ni, H. (2012). The Effects of Affective Factors in SLA and Pedagogical Implications. Theory and Practice in Language Studies, 2(7), pp. 1508-1513.

Occhipinti, A. (2009). Foreign Language Anxiety in in-Class Speaking Activities: Two Learning Contexts in Comparison. An MA Thesis Presented to The Department of Literature, Area Studies and European Languages, The University of Oslo in Partial fulfillment for MA.

Örmeci, D., N. (2013).How do the psycholinguistic factors affect the foreign language learning process of preparatory class students? The Internet Journal Language, Culture and Society, 122-130

Retrieved from: http://aaref.com.au/en/publications/journal/

Önem, E. (2010). The Relationship Among State-Trait Anxiety, Foreign Language Anxiety and Test Anxiety. TÖMER Dil Dergisi. (148) 17-36.

Rafi, S., E. (2008). The Relationship between Self-Esteem and Gender, Grade Level and Academic Achievement, in Secondary Schools' Classes in Lebanon. PH. D. Thesis.

Riasati, M., J. (2011). Language Learning Anxiety from EFL Learners' Perspective. Middle-East Journal of Scientific Research 7(6), 907-914.

Ruhi, K. (1985). A Comparative Study of the Self-Esteem of the Pakistani Minority and the Indigenous Children in Scotland. PH. D. Thesis.

Sila, A.Y., 2010. Young adolescent students' foreign language anxiety in relation to language skills at different levels. The Journal of International Social Research, 3(11), 83e91.

Smith, B., Schroth, T. (2014) Anxiety in the Foreign Language Classroom. ISSN 1096-1453. 18, 1.

Suleimenova, Z. (2013). Speaking anxiety in a foreign language classroom in Kazakhstan. Procedia - Social and Behavioral Sciences, 93, 1860-1868.

Tanveer, M. (2007). Investigations of the factors that cause language anxiety for ESL/EFL learners in learning speaking skills and the influence it casts on communication in the target language (Unpublished master's thesis). University of Glasgow, Scotland.

Tóth, Z.(2011).Foreign Language Anxiety And Advanced Efl Learners: An Interview Study. WoPaLP, 5

Trang, T. T. T. (2012). A Review of Horwitz, Horwitz and Cope Theory of Foreign Language Anxiety and the Challenges to the Theory. English Language Teaching, 5(1), 69-75. http://dx.doi.org/10.5539/elt.vn1p69

Tseng, S.F. (2012). The Factors Cause Language Anxiety for ESL/EFL Learners in Learning Speaking. WHAMPOA An Interdisciplinary Journal, 63, 75-90.

Tüm, D., \& Kunt, N. (2013). Speaking Anxiety among EFL Student Teachers. Hacettepe Üniversitesi Eğitim Fakültesi Dergisi, 28(3), 385-399

Wang, N. (2005). Beliefs about language learning and foreign language anxiety: A study of university students learning English as a foreign language in Mainland China. (Unpublished master's thesis). University of Victoria, Saanich, British Colombia.

Yahya, M. (2013). Measuring speaking anxiety among speech communication course students at the Arab American University of Jenin (AAUJ). European Social Sciences Research Journal, 1(3), 229-248.

Yang, H., C. (2012). Language Anxiety, Acculturation, and L2 Self: A Relational Analysis in the Taiwanese Cultural Context. Electronic Journal of Foreign Language Teaching, 9(2) 183-193

Zare, P., \& Riasati, M. J. (2012). The relationship between language learning anxiety, self-esteem, and academic level among Iranian EFL learners. University Putra Malaysia Press, 20(1), 219-225.

Zhanibek, A. (2001). The relationship between language anxiety and students' participation in foreign language classes (Unpublished master's thesis). Bilkent University, Turkey

Zheng, Y. (2010). Chinese University Students' Motivation, Anxiety, Global Awareness, Linguistic Confidence and English Test Performance (Doctoral dissertation). Queen's University, Canada, Library and Archives Canada. Retrieved from http://hdl.handle.net/1974/5378 